\title{
Arguments for a national questionnaire-based screening for hidradenitis suppurativa in Denmark
}

\author{
Peter Theut Riis ${ }^{1}$, Pernille Linds $\emptyset$ Andersen $^{1}$, Gregor Borut Jemec ${ }^{1}$
}

\begin{abstract}
Introduction: Hidradenitis suppurativa (HS) is a chronic inflammatory disease. HS patients develop painful subcutaneous nodules, primarily in the intertriginous regions. Early diagnosis is crucial to initiate appropriate treatment, which may prevent disease progression. The cost of treatment increases with disease severity. Studies have found a considerable diagnostic delay in HS. Screening programs may reduce diagnostic delay and allow for better utilization of resources.

Methods: Arguments for implementing an HS screening program were explored based on the 10 WHO criteria for implementing screening programs.

Results: HS is an important health problem due to its prevalence and the adverse effects of the disease. Facilities for treatment and diagnosis exist, and the validated screening questionnaire is considered acceptable to the population. HS patients should be seen by a dermatologist and treated accordingly. Medical expenses increase with disease severity, and finding patients with early-stage HS is considered cost-effective.

Conclusions: We consider a screening program as valuable for public healthcare. Patients can avoid extensive surgery or treatment with biologics if disease progression is prevented, and this will reduce medical expenses for the public healthcare system. Politicians should consider implementing a screening program for HS.
\end{abstract}

Keywords: screening, hidradenitis suppurativa, acne inversa

\section{Introduction}

Hidradenitis suppurativa (HS) is a chronic inflammatory skin disease. Patients suffering from this disease recurrently develop painful subcutaneous nodules, primarily in the intertriginous regions; for example, the axilla and the groin (1-3).

In approximately $60 \%$ of patients, the majority of the inflammatory nodules progress to abscesses, or pus-filled cavities that drain laterally through cutaneous tunnels to the surface of the skin $(4,5)$. The cutaneous tunnels heal with scarring, and during the repeated cycles of inflammation, abscesses, and scarring permanent draining fistula gradually begin to mar the skin.

The presence of permanent cutaneous tunnels predisposes patients to further inflammation, more scarring, and more tunnels, in what becomes a vicious cycle.

The disease affects females three times as often as males, and the disease is associated with smoking and obesity. Smoking is associated with the presence of the disease, and also with more advanced disease stages (6-14). Several studies have shown that obese people suffer from HS more often and that obese HS patients tend to have more severe disease than non-obese patients. In addition, remission is less likely for obese patient $(8,10,12,15-19)$.

To combat the disease, dermatologists rely on three avenues of care: reducing inflammation with anti-inflammatory systemics or topical medication (20-27), surgical removal of tunnels and fistula (1, 28-31), and adjuvant therapy in the form of weight reduction and smoking cessation $(1,32)$.

Many patients are misdiagnosed by their general practitioner due to the clinical presentation of HS and its similarity to simple abscesses. The taboo of having an abscess, a disease entity associated with uncleanness, prevents many from contacting a general practitioner in the first place (33). For HS, the diagnostic delay is on average 7.2 years, compared to 1.6 years for psoriasis (33). Screening the general population or part of it might be a way to reduce this delay. The cost of treating HS increases with increasing duration of the disease because the patients accumulate scar tissue over time, as explained above (34). In addition to reducing the diagnostic delay, screening will allow for better utilization of healthcare resources due to the cheaper lifetime treatment cost for patients that start treatment early.

Table 1 | World Health Organization recommendations for screening programs.

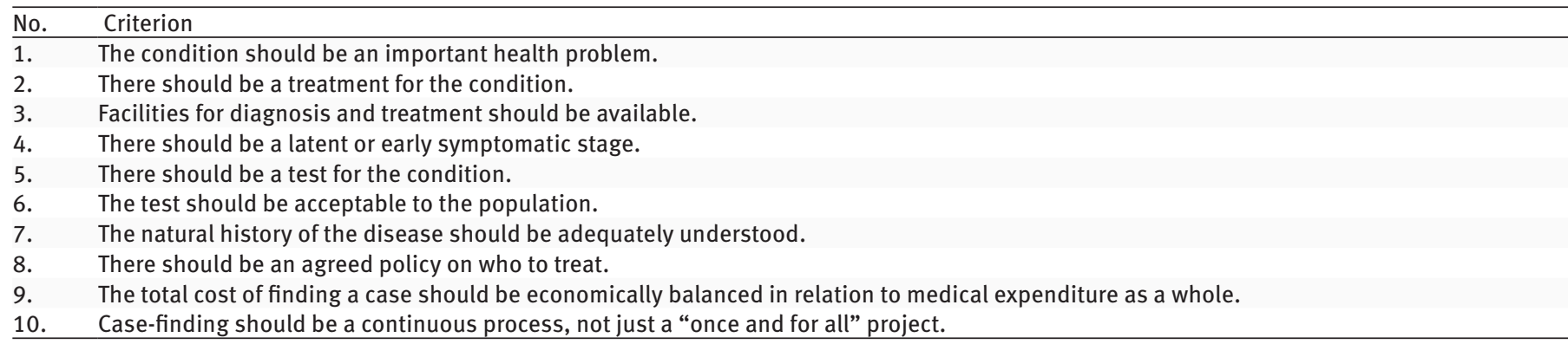




\section{Methods}

The World Health Organization has established 10 criteria for implementing a screening program; see Table 1 (35). Each criterion for implementing a screening program was examined in the context of HS to determine whether a HS screening program may be recommended.

\section{Results and discussion}

\section{The condition should be an important health problem.}

The importance of any medical condition as a health problem arguably rests on two pillars. One is how adversely patients are affected by the condition. The second is the prevalence of the condition in the general population. As outlined above, HS is a very distressing condition.

\section{Adverse effects}

\section{Pain}

Patients with HS reported the highest pain scores when compared to psoriasis, skin tumors, eczema, acne, and other skin diseases (36). A study of 4,010 dermatological patients and 1,359 controls focusing on Health Related Quality of Life (HRQoL) using the EuroQol 5-Dimensions (EQ5D) tool found that, of all skin conditions, HS was the one most associated with the pain/discomfort domain (37).

The same study found HS patients to have among the three lowest possible utility scores using EQ5D with a mean score of 56.9, surpassed only by leg ulcers (56.0) and prurigo (56.5). However, a linear regression showed that HS had the most impact on self-reported quality of life on a visual analogue score HRQoL measurement included in the $\mathrm{EQ}_{5} \mathrm{D}$, after adjusting for confounders (37). When asking patients how HS affects their lives, social isolation and feelings of dependency are common themes (38). They feel unloved and unworthy of love due to scarring and inflammation (38).

\section{Quality of life}

Several tools have been employed to measure the quality of life for patients with HS. Instruments range from the dermatologically focused Dermatologic Life Quality Index (DLQI) (39) to more general tools such as the Short Form-36 (SF-36) (40). Patients have significantly decreased quality of life (QoL), regardless of the tool used (38, 41-45). Several of these studies also demonstrate that QoL decreases as the disease advances through Hurley stages (41-44).

\section{Depression}

HS patients are prone to depression and score higher on depression instruments such as the Major Depression Inventory $(36,46)$ and Hospital Anxiety and Depression Scale than healthy controls (47). Questionnaire-based studies find that between 9\% and 39\% of patients suffer from depression, with higher scores correlated with disease severity $(42,48)$.

\section{Co-morbidities}

HS is associated with several comorbidities, some related to metabolic syndrome, such as obesity, hypertension, dyslipidemia, and diabetes $(17-19,49)$, but also thyroid disorders, psychiatric disorders-especially within the affective spectrum-acne, polycystic ovarian syndrome, lymphoma, drug dependence, and squamous cell carcinoma $(9,12,16,49)$.

\section{Professional activity}

Because HS often debuts in patients' early 20s, it affects the active years in which people usually take part in education and establish themselves on the job market. This may be part of the reason for the low socioeconomic status of HS patients (50). The acute disability associated with disease flares significantly increases absenteeism and can prove a barrier for promotion or advancement (43). A Danish survey of hospital-recruited HS patients $(n=215)$ found that $25.1 \%$ of non-retired, non-student HS patients were currently unemployed. This is a significant difference from the national average of $6.2 \%(51)$.

\section{Prevalence}

Several studies have addressed the issue of prevalence, the second pillar of the importance criterion. However, given the scope of this article, prevalence studies conducted in Denmark are the focus of this discussion.

Two smaller studies determined the prevalence of HS to be $4 \%$ (52) and 4.1\% (53), respectively. However, one article examined young adults at a clinic for sexually transmitted diseases (53) and the other used an unvalidated questionnaire distributed to nurses (52). Population studies have estimated the prevalence to be between $0.97 \%$ (54) and $2.1 \%$ (13) using an unvalidated (54) and validated questionnaire (13), respectively (55). For comparison, a recent study found a prevalence of $2.2 \%$ for psoriasis in Denmark (56).

No Danish incidence studies have been conducted, but an American study found an incidence of 6.0 (95\% CI: 5.2-6.7) per 100,000 person-years, with up to 18.4 per 100,000 person-years in females aged 20 to 29 (12). Studies of prevalence in the United States found a lower prevalence than Danish studies-namely, between $0.05 \%$ and $0.20 \%$ (57-60) - which must be considered when extrapolating the American incidence to the Danish population.

\section{There should be a treatment for the condition.}

Several treatments exist for HS, but none of them are uniformly effective and several attempts are often needed to find a treatment suitable for an individual patient. In general, topical treatments are employed as a first-line treatment, followed by prolonged antibiotic courses as a second-line treatment, using biologics only if antibiotic therapy fails. Permanent scar tissue from repeated flares necessitates surgical intervention, which removes large areas of flare-prone skin (1).

Evidence-based topical treatments include resorcinol (20), clindamycin $(22,25)$, and intralesional triamcinolone injections (61). If topical treatments are unable to control inflammation, systemic therapies are added.

For systemic therapy, the European guidelines recommend tetracycline (25) and a combination of clindamycin and rifampicin $(24,62,63)$ as the go-to drugs for reducing inflammation (32). Several other anti-inflammatory drugs such as corticosteroids (64, $65)$, dapsone $(66-68)$, and ciclosporin $(69,70)$ can be employed (32) before trying biologic treatments; however, the evidence level is unsatisfactory (71).

Adalimumab (26, 27, 72, 73), anakinra (74), and ustekinumab (75) have all shown promising results for the treatment of HS. The evidence level is higher for adalimumab (76), which is currently the only drug with HS as a registered indication.

Surgical intervention is needed to treat the scarring and tunnels formed by HS (77). Although extensive surgery is indicated in 
widespread disease and results in a low recurrence rate (78), the procedure can be disfiguring (77). More localized surgical methods have a better cosmetic outcome, but they have higher rates of recurrence (61).

Incision and drainage can be employed for immediate pain relief if an abscess is present, but solid inflamed tumors obviously should not be incised $(79,80)$. The tissue-saving surgical technique, deroofing, utilizes a probe to explore the extent of cutaneous tunnels and subsequently removes the roof of these tunnels (81).

Skin-Tissue-sparing Excision with Electrosurgical Peeling (STEEP) sequentially removes layers of the skin until healthy tissue is reached in order to preserve the maximum amount of healthy tissue (82).

Wide excision includes a margin of disease-free tissue and can be extensive. The surgical defects are closed with various techniques, including a split-thickness skin graft or flaps, but are occasionally left to heal by secondary intention, where the wound is left open and heals by granulation $(28,77,83-86)$.

Treatment algorithms are beyond the scope of this article, but they are extensively covered in the European S1 guidelines (32) and in a recent review by Saunte et al. (77).

\section{Facilities for diagnosis and treatment should be available.}

A potential screening program should primarily allocate resources to private dermatologists, but to surgical specialists as well. Private dermatologists are able to diagnose and manage the majority of HS patients. Extensive surgery can be performed by a combination of private or hospital-based dermatologists, plastic surgeons, gynecologists, and abdominal surgeons, depending on the location of scarring. The facilities needed exist and treatment is available as discussed above, but both will obviously require funding to handle an increase in HS patients.

\section{There should be a latent or early symptomatic stage.}

HS can be divided in three so-called Hurley Stages (87), created to identify the level of scar tissue in a single region. Hurley I is defined as abscess formation, single or multiple, without sinus tracts or cicatrization; Hurley II is characterized by recurrent abscesses with tract-formation and cicatrization, single or multiple, widely separated lesions; and Hurley III is defined as diffuse or near-diffuse involvement, or multiple interconnected tracts and abscesses across the entire area.

Because scar tissue is permanent, patients can progress through the Hurley stages, but they can never regress without surgical intervention. Assessment of a patient's surgical needs is easily performed by using the Hurley classification system because patients categorized as Hurley II and III require surgery. Therefore, Hurley stage I is a perfect example of an early symptomatic stage.

Prevalences of the three stages have only been examined in a hospital setting, skewing the distribution toward the severe spectrum $(16,88)$. A hospital-based sample reported 68.2\% Hurley I, 27.6\% Hurley II, and 3.9\% Hurley III patients (16).

\section{There should be a test for the condition.}

A validated two-stage questionnaire was developed by Vinding et al. in 2014 (13). Because patients generally refer to the lesions of HS as boils, the initial question is phrased: "Have you had an outbreak of boils during the last 6 months?” If responders answer affirmatively, they are presented with the follow-up question: "Where and how many boils have you had?" with five different location options listed (axilla, groin, genitals, under the breasts, and other locations) (13). If patients answer "yes" to the initial question and report two or more boils in the follow-up question, responders can be categorized as suffering from HS.

This test has a sensitivity of $90 \%$, a specificity of $97 \%$, a positive predictive value of $96 \%$, and a negative predictive value of $92 \%$ (13). We suggest distributing the questionnaire to the population or part of the population and instructing responders with a positive response to visit their private dermatologist for confirmation.

\section{The test should be acceptable to the population.}

The questionnaire can be distributed online and takes less than 2 minutes to answer. In the Danish context, the state-issued e-mail address can be used. Individuals that do not have such an e-mail address (less than $10 \%$ of the population) can receive the questionnaire by mail and answer on paper.

The disease is not well known, and from anecdotal experience most patients react with a chuckle when answering the questionnaire, making it unlikely to induce fear of developing the disease at a later stage. Before starting nationwide screening, the psychological effect of the questions should be explored properly.

\section{The natural history of the disease should be adequately understood.}

HS is a disease of the hair follicles. Infundibular keratosis and hyperplasia of the follicle epithelium cause occlusion of the hair follicle (89-92). The accumulation of debris gives rise to the formation of a cyst and later to rupture of the follicle $(93,94)$. The introduction of follicle content into the dermis causes a massive inflammatory response. The inflammatory cytokines present in HS lesions are still under investigation. So far, increased levels of tumor necrosis factor-a (TNF-a) (95-97) and interferon-y (98) along with increased levels of several interleukins (IL) have been found. IL-1 $\beta$, IL-6, IL-8, IL-10, IL-12, IL-17A, IL-20, IL-22, IL-23, IL24, IL-26, IL-32, IL-32a, IL-32 $\beta$, IL-36a, IL-36 $\beta$, and IL-36y have been examined and found to be increased compared to controls (95, 97-105).

Histologically, the disease is characterized by a lymphocytic infiltrate and the subsequent loss of sebaceous glands. The later stages of the disease often present an infiltrate of neutrophils, monocytes, and mast cells $(95,105,106)$.

The disease typically debuts in the early $20 \mathrm{~s}(9,107)$ and is considered chronic. A study has showed that $39.4 \%$ of patients experienced remission after a mean of 22 years (8). This finding is supported by a population survey that showed that, as age increases, the prevalence decreases correspondingly (13). In general, disease severity tapers off around the age of 55 , although activity can persist for far longer $(9,14)$.

\section{There should be an agreed policy on who to treat.}

The suggested screening questionnaire was developed based on the disease definition accepted at the HS foundation meeting in Dessau and modified in San Francisco in 2009 (13). The following three criteria must be met: 1) typical lesions (i.e., deep-seated painful nodules, or "blind boils" in early lesions) and abscesses, draining sinus, bridged scars, and "tombstone" double-ended pseudo-comedones in secondary lesions; 2) typical topography (i.e., axillae, groin, perineal region, buttocks, and infra- and intermammary folds); and 3) chronicity and recurrences.

The screening questions cover all three criteria; recipients can, however, incorrectly identify non-boil lesions as boils, but 
the questionnaire is validated with high sensitivity and excellent specificity (13). We suggest that all patients identified as HS patients should be seen by a dermatologist for confirmation and treatment.

\section{The total cost of finding a case should be economically balanced in relation to medical expenditure as a whole.}

The balance between the cost of identifying a case and the associated medical expenditure as a whole will depend on the country. In Denmark, more than 90\% of Danes are in the "e-boks" e-mail system (108), a personal e-mail account linked to the unique Danish Civil Registration system, which supplies each Dane with an identification number. This allows for easy e-mail access to the majority of Danes. The e-boks system is currently utilized by the Danish Hospital system when communicating with patients. $\mathrm{Pa}$ tients that have not agreed to use e-boks still receive all communication in an analogue paper format. Using the infrastructure already in place and sending the questionnaire in an online format makes screening the adult population a low-cost endeavor.

Early treatment of lesions to prevent the formation of inflammation-inducing scar tissue is of paramount importance in managing the disease, both from a patient perspective and an economic perspective (34). The more severe the disease, the more expensive it is to treat. The cost of surgery increases the more extensive the area, and the biologic medication used to treat the most severe inflammation is notoriously expensive.

A British study estimated that patients with an ICD1o code of L73.2 (HS) as a primary diagnosis had a mean hospital utilization cost of £2,027 ( €2,300) per year, with the highest cost for surgery (109). In Denmark, patients cost even more because the state pays the additional cost for medication if the total yearly expense of all medication exceeds $€ 537$ (110). Three months of treatment with tetracyclin costs $€ 108$ (111), and a combination treatment of rifampicin and clindamycin costs €266 (112, 113).

Most patients use these medications more than 3 months per year, and added to that comes the cost of topical treatments, bandages, painkillers (114), and other medicine. Recall that the psychiatric comorbidities increase with severity (41-44), and that these patients are prone to depression, and there is also the cost of potential anti-depressants as well as other psychiatric therapies. In our experience, most HS patients receive financial support for their medication.

Adalimumab, the only registered drug for HS and the most widely used biologic, has a market price of €2,975 for 14 days of treatment, which corresponds to $€_{38,680}$ per year. Adalimumab is dispensed by and paid for in full by the hospital. In addition to medical expenses, public healthcare also covers the full cost of a visit to the dermatologist if the referral is of a non-cosmetic character.

The cost of HS patients in Denmark has never been examined in full, and the benefit of a screening program cannot be accurately calculated before actually implementing it. We can, however, venture an educated guess. We suggest sending the screening questionnaire every 5 years to adults aged 18 to 40. Patients screened positive are referred to either a private dermatologist or a hospital-based dermatologist for confirmation and treatment.

For the total account of the calculation, see Supplementary Table 1 . The entire screening process is estimated to cost approximately $€ 422,932$. In perspective, that is only slightly above the cost of keeping two patients on adalimumab treatment for a 5-year period $\left(€_{3} 86,800\right)$. If the screening program can prevent at least two patients from reaching the last-line-treatment of adalimumab for 5 years during their lifetime, it will already be cost-effective, and added to that are the secondary financial benefits of early diagnosis.

\section{Case-finding should be a continuous process, not just a "once and for all" project.}

As described above, we suggest screening the population every 5 years. Assuming an incidence of 5.2 to 6.7 per 100,000 person years (12), approximately 1,013 to 1,305 new cases will develop after 5 years, making subsequent screenings slightly less expensive.

\section{Conclusion}

Whether the criteria for initiating screening for HS are fulfilled is a matter of interpretation and a political point of view. The farranging effect of a screening program is impossible to predict before implementing it, but in our humble estimation a screening program will be of significant benefit to patients and to public healthcare as a whole. It is reasonable to suggest that a screening program for HS would be cost-effective and in the long run would free up healthcare resources to be utilized elsewhere. In conclusion, politicians should consider implementing a screening program for HS.

\section{Conflict of interest}

PTR and PLA declare no conflict of interest. GB Jemec has received honoraria from AbbVie, Coloplast, Pfizer, Pierre Fabre, Inflarx, MSD, Novartis, and UCB for participation on advisory boards, grants from Abbvie, Leo Pharma, Novartis, Janssen-Cilag, Regeneron, UCB, and Sanofi for participation as an investigator, and speaker honoraria from AbbVie, Galderma, and Leo Pharma.

\section{References}

1 Jemec GB. Clinical practice. Hidradenitis suppurativa. N Engl J Med. 2012;366: 158-64.

2. Revuz J. Hidradenitis suppurativa. J Eur Acad Dermatol Venereol. 2009;23:98598.

3. Alikhan A, Lynch PJ, Eisen DB. Hidradenitis suppurativa: a comprehensive review. J Am Acad Dermatol. 2009;60:539-61; quiz 62-3.

4. Micheletti RG. Natural history, presentation, and diagnosis of hidradenitis suppurativa. Semin Cutan Med Surg. 2014;33:S51-3.

5. von der Werth JM, Williams HC. The natural history of hidradenitis suppurativa. J Eur Acad Dermatol Venereol. 2000;14:389-92.

6. Happle R, Konig A. Smoker's boils. Dermatology. 2011;222:282-4.

7. Konig A, Lehmann C, Rompel R, Happle R. Cigarette smoking as a triggering factor of hidradenitis suppurativa. Dermatology. 1999;198:261-4.

8. Kromann CB, Deckers IE, Esmann S, Boer J, Prens EP, Jemec GB. Risk factors, clinical course and long-term prognosis in hidradenitis suppurativa: a crosssectional study. Br J Dermatol. 2014;171:819-24.

9. Miller IM, MCAndrew RJ, Hamzavi I. Prevalence, risk factors, and comorbidities of hidradenitis suppurativa. Dermatol Clin. 2016;34:7-16.

10. Sartorius K, Emtestam L, Jemec GB, Lapins J. Objective scoring of hidradenitis suppurativa reflecting the role of tobacco smoking and obesity. $\mathrm{Br}$ J Dermatol. 2009;161:831-9. 
11. Schrader AM, Deckers IE, van der Zee HH, Boer J, Prens EP. Hidradenitis suppurativa: a retrospective study of 846 Dutch patients to identify factors associated with disease severity. J Am Acad Dermatol. 2014;71:460-7.

12. Vazquez BG, Alikhan A, Weaver AL, Wetter DA, Davis MD. Incidence of hidradenitis suppurativa and associated factors: a population-based study of Olmsted County, Minnesota. J Invest Dermatol. 2013;133:97-103.

13. Vinding GR, Miller IM, Zarchi K, Ibler KS, Ellervik C, Jemec GB. The prevalence of inverse recurrent suppuration: a population-based study of possible hidradenitis suppurativa. Br J Dermatol. 2014;170:884-9.

14. Revuz JE, Canoui-Poitrine F, Wolkenstein P, Viallette C, Gabison G, Pouget F, et al. Prevalence and factors associated with hidradenitis suppurativa: results from two case-control studies. J Am Acad Dermatol. 2008;59:596-601.

15. Kromann CB, Ibler KS, Kristiansen VB, Jemec GB. The influence of body weight on the prevalence and severity of hidradenitis suppurativa. Acta Derm Venereol. 2014;94:553-7.

16. Canoui-Poitrine F, Revuz JE, Wolkenstein P, Viallette C, Gabison G, Pouget F, et al. Clinical characteristics of a series of 302 French patients with hidradenitis suppurativa, with an analysis of factors associated with disease severity. J Am Acad Dermatol. 2009;61:51-7.

17. Gold DA, Reeder VJ, Mahan MG, Hamzavi IH. The prevalence of metabolic syndrome in patients with hidradenitis suppurativa. J Am Acad Dermatol. 2014;70: 699-703.

18. Miller IM, Ellervik C, Vinding GR, Zarchi K, Ibler KS, Knudsen KM, et al. Association of metabolic syndrome and hidradenitis suppurativa. JAMA Dermatol. 2014; 150:1273-80.

19. Sabat R, Chanwangpong A, Schneider-Burrus S, Metternich D, Kokolakis G, Kurek A, et al. Increased prevalence of metabolic syndrome in patients with acne inversa. PLoS One. 2012;7:e31810.

20. Boer J, Jemec GB. Resorcinol peels as a possible self-treatment of painful nodules in hidradenitis suppurativa. Clin Exp Dermatol. 2010;35:36-40.

21. Riis PT, Boer J, Prens EP, Saunte DM, Deckers IE, Emtestam L, et al. Intralesional triamcinolone for flares of hidradenitis suppurativa (HS): a case series. J Am Acad Dermatol. 2016;75:1151-5.

22. Clemmensen 0J. Topical treatment of hidradenitis suppurativa with clindamycin. Int J Dermatol. 1983;22:325-8.

23. Bettoli V, Zauli S, Borghi A, Toni G, Minghetti S, Ricci M, et al. Oral clindamycin and rifampicin in the treatment of hidradenitis suppurativa-acne inversa: a prospective study on 23 patients. J Eur Acad Dermatol Venereol. 2014;28:125-6.

24. Gener G, Canoui-Poitrine F, Revuz JE, Faye O, Poli F, Gabison G, et al. Combination therapy with clindamycin and rifampicin for hidradenitis suppurativa: a series of 116 consecutive patients. Dermatology. 2009;219:148-54.

25. Jemec GB, Wendelboe P. Topical clindamycin versus systemic tetracycline in the treatment of hidradenitis suppurativa. J Am Acad Dermatol. 1998;39:971-4.

26. Kimball AB, Kerdel F, Adams D, Mrowietz U, Gelfand IM, Gniadecki R, et al. Adalimumab for the treatment of moderate to severe hidradenitis suppurativa: a parallel randomized trial. Ann Intern Med. 2012;157:846-55.

27. Kimball AB, Okun MM, Williams DA, Gottlieb AB, Papp KA, Zouboulis CC, et al. Two phase 3 trials of adalimumab for hidradenitis suppurativa. N Engl J Med. 2016;375:422-34.

28. Alharbi Z, Kauczok J, Pallua N. A review of wide surgical excision of hidradenitis suppurativa. BMC Dermatol. 2012;12:9.

29. Ritz JP, Runkel N, Haier J, Buhr HJ. Extent of surgery and recurrence rate of hidradenitis suppurativa. Int J Colorectal Dis. 1998;13:164-8.

30. Lapins J, Sartorius K, Emtestam L. Scanner-assisted carbon dioxide laser surgery: a retrospective follow-up study of patients with hidradenitis suppurativa. J Am Acad Dermatol. 2002;47:280-5.

31. van der Zee HH, Prens EP, Boer J. Deroofing: a tissue-saving surgical technique for the treatment of mild to moderate hidradenitis suppurativa lesions. I Am Acad Dermatol. 2010;63:475-80.

32. Zouboulis CC, Desai N, Emtestam L, Hunger RE, Ioannides D, Juhasz I, et al. European $\mathrm{S} 1$ guideline for the treatment of hidradenitis suppurativa/acne inversa. J Eur Acad Dermatol Venereol. 2015;29:619-44.

33. Saunte DM, Boer J, Stratigos A, Szepietowski JC, Hamzavi I, Kim KH, et al. Diagnostic delay in hidradenitis suppurativa is a global problem. $\mathrm{Br} J$ Dermatol. 2015;173:1546-9.

34. Martorell A, Caballero A, Gonzalez Lama Y, Jimenez-Gallo D, Lazaro Serrano M, Miranda J, et al. Management of patients with hidradenitis suppurativa. Actas dermo-sifiliograficas. 2016;107 Suppl 2:32-42.

35. Wilson JMG, Jungner G. Principles and practices of screening for disease. Geneva, Switzerland: World Health Organization; 1968. Public Health Papers no. 34.

36. Onderdijk AJ, van der Zee HH, Esmann S, Lophaven S, Dufour DN, Jemec GB, et al. Depression in patients with hidradenitis suppurativa. J Eur Acad Dermatol Venereol. 2013;27:473-8.

37. Balieva F, Kupfer J, Lien L, Gieler U, Finlay AY, Tomas-Aragones L, et al. The burden of common skin diseases assessed with the $\mathrm{EQ}_{5} \mathrm{D}$ : a European multicentre study in 13 countries. Br J Dermatol. 2017;176:1170-8.

38. Esmann S, Jemec GB. Psychosocial impact of hidradenitis suppurativa: a qualitative study. Acta Derm Venereol. 2011;91:328-32.

39. Finlay AY, Khan GK. Dermatology Life Quality Index (DLQI)-a simple practical measure for routine clinical use. Clin Exp Dermatol. 1994;19:210-6.

40. Ware JE Jr, Sherbourne CD. The MOS 36-item short-form health survey (SF-36). I. Conceptual framework and item selection. Med Care. 1992;30:473-83.
41. Gooderham M, Papp K. The psychosocial impact of hidradenitis suppurativa. Am Acad Dermatol. 2015;73:S19-22.

42. Matusiak L, Bieniek A, Szepietowski JC. Psychophysical aspects of hidradenitis suppurativa. Acta Derm Venereol. 2010;90:264-8.

43. Matusiak L, Bieniek A, Szepietowski JC. Hidradenitis suppurativa markedly decreases quality of life and professional activity. J Am Acad Dermatol. 2010;62: 706-8, 708.e1.

44. Alavi A, Anooshirvani N, Kim WB, Coutts P, Sibbald RG. Quality-of-life impairment in patients with hidradenitis suppurativa: a Canadian study. Am J Clin Dermatol. 2015;16:61-5.

45. von der Werth JM, Jemec GB. Morbidity in patients with hidradenitis suppurativa. Br J Dermatol. 2001;144:809-13.

46. Bech P, Timmerby N, Martiny K, Lunde M, Soendergaard S. Psychometric evaluation of the Major Depression Inventory (MDI) as depression severity scale using the LEAD (Longitudinal Expert Assessment of All Data) as index of validity. BMC Psychiatry. 2015;15:190.

47. Kurek A, Johanne Peters EM, Sabat R, Sterry W, Schneider-Burrus S. Depression is a frequent co-morbidity in patients with acne inversa. J Dtsch Dermatol Ges. 2013;11:743-9, 743-50.

48. Thorlacius L, Cohen AD, Gislason GH, Jemec GBE, Egeberg A. Increased suicide risk in patients with hidradenitis suppurativa. J Invest Dermatol. 2018;138:52-7.

49. Shlyankevich J, Chen AJ, Kim GE, Kimball AB. Hidradenitis suppurativa is a systemic disease with substantial comorbidity burden: a chart-verified case-control analysis. J Am Acad Dermatol. 2014;71:1144-50.

50. Deckers IE, Janse IC, van der Zee HH, Nijsten T, Boer J, Horvath B, et al. Hidrad enitis suppurativa (HS) is associated with low socioeconomic status (SES): a cross-sectional reference study. J Am Acad Dermatol. 2016;75:755-9e1.

51. Theut Riis P, Thorlacius L, Knudsen List E, Jemec GBE. A pilot study of unemployment in patients with hidradenitis suppurativa in Denmark. Br J Dermatol. 2017; 176:1083-5.

52. Jemec GB. The symptomatology of hidradenitis suppurativa in women. Br J Dermatol. 1988;119:345-50.

53. Jemec GB, Heidenheim M, Nielsen NH. The prevalence of hidradenitis suppurativa and its potential precursor lesions. J Am Acad Dermatol. 1996;35:191-4.

54. Jemec GB, Heidenheim M, Nielsen NH. [Prevalence of hidradenitis suppurativa in Denmark]. Ugeskrift for Læger. 1998;160:847-9.

55. Jemec GB, Kimball AB. Hidradenitis suppurativa: epidemiology and scope of the problem. J Am Acad Dermatol. 2015;73:S4-7.

56. Egeberg A, Skov L, Gislason GH, Thyssen JP, Mallbris L. Incidence and prevalence of psoriasis in Denmark. Acta Derm Venereol. 2017;97:808-12.

57. Lookingbill DP. Yield from a complete skin examination. Findings in 1157 new dermatology patients. J Am Acad Dermatol. 1988;18:31-7.

58. Sung S, Kimball AB. Counterpoint: analysis of patient claims data to determine the prevalence of hidradenitis suppurativa in the United States. J Am Acad Dermatol. 2013;69:818-9.

59. Cosmatos I, Matcho A, Weinstein R, Montgomery MO, Stang P. Analysis of patient claims data to determine the prevalence of hidradenitis suppurativa in the United States. J Am Acad Dermatol. 2013;68:412-9.

6o. Shahi V, Alikhan A, Vazquez BG, Weaver AL, Davis MD. Prevalence of hidradenitis suppurativa: a population-based study in Olmsted County, Minnesota. Dermatology. 2014;229:154-8.

61. Riis PT, Boer J, Deckers I, Prens EP, Emstedam L, Saunte DML, et al. Hidradenitis suppurativa intralesional injections with corticosteroids - HILIC. Exp Dermatol. 2016;25:11.

62. Mendonca CO, Griffiths CE. Clindamycin and rifampicin combination therapy for hidradenitis suppurativa. Br J Dermatol. 2006;154:977-8.

63. van der Zee HH, Boer J, Prens EP, Jemec GB. The effect of combined treatment with oral clindamycin and oral rifampicin in patients with hidradenitis suppurativa. Dermatology. 2009;219:143-7.

64. Danto JL. Preliminary studies of the effect of hydrocortisone on hidradenitis suppurativa. J Invest Dermatol. 1958;31:299-300.

65. Norris JFB, Cunliffe WJ. (43) Hidradenitis suppurativa and response to oral steroids. Br J Dermatol. 1987;117:96.

66. Yazdanyar S, Boer J, Ingvarsson G, Szepietowski JC, Jemec GB. Dapsone therapy for hidradenitis suppurativa: a series of 24 patients. Dermatology. 2011;222: 342-6.

67. Kaur MR, Lewis HM. Hidradenitis suppurativa treated with dapsone: a case series of five patients. J Dermatolog Treat. 2006;17:211-3.

68. Hofer T, Itin PH. [Acne inversa: a dapsone-sensitive dermatosis]. Hautarzt. 2001; 52:989-92. German.

69. Gupta AK, Ellis CN, Nickoloff BJ, Goldfarb MT, Ho VC, Rocher LL, et al. Oral cyclosporine in the treatment of inflammatory and noninflammatory dermatoses. A clinical and immunopathologic analysis. Arch Dermatol. 1990;126:339-50.

70. Rose RF, Goodfield MJ, Clark SM. Treatment of recalcitrant hidradenitis suppurativa with oral ciclosporin. Clin Exp Dermatol. 2006;31:154-5.

71. Ingram JR, Woo PN, Chua SL, Ormerod AD, Desai N, Kai AC, et al. Interventions for hidradenitis suppurativa. Cochrane Database Syst Rev. 2015:CD010081.

72. Scheinfeld N, Sundaram M, Teixeira H, Gu Y, Okun M. Reduction in pain scores and improvement in depressive symptoms in patients with hidradenitis suppurativa treated with adalimumab in a phase 2 , randomized, placebo-controlled trial. Dermatol Online J. 2016;22. 
73. Sotiriou E, Goussi C, Lallas A, Chovarda E, Apalla Z, Lazaridou E, et al. A prospective open-label clinical trial of efficacy of the every week administration of adalimumab in the treatment of hidradenitis suppurativa. J Drugs Dermatol. 2012; 11:S15-20.

74. Tzanetakou V, Kanni T, Giatrakou S, Katoulis A, Papadavid E, Netea MG, et al. Safety and efficacy of anakinra in severe hidradenitis suppurativa: a randomized clinical trial. JAMA Dermatol. 2016;152:52-9.

75. Blok JL, Li K, Brodmerkel C, Horvatovich P, Jonkman MF, Horvath B. Ustekinumab in hidradenitis suppurativa: clinical results and a search for potential biomarkers in serum. Br J Dermatol. 2016;174:839-46.

76. Ingram JR, Woo PN, Chua SL, Ormerod AD, Desai N, Kai AC, et al. Interventions for hidradenitis suppurativa: a Cochrane systematic review incorporating GRADE assessment of evidence quality. Br J Dermatol. 2016;174:970-8.

77. Saunte DML, Jemec GBE. Hidradenitis suppurativa: advances in diagnosis and treatment. JAMA. 2017;318:2019-32.

78. Mehdizadeh A, Hazen PG, Bechara FG, Zwingerman N, Moazenzadeh M, Bashash $M$, et al. Recurrence of hidradenitis suppurativa after surgical management: a systematic review and meta-analysis. J Am Acad Dermatol. 2015;73:S70-7.

79. Janse I, Bieniek A, Horvath B, Matusiak L. Surgical procedures in hidradenitis suppurativa. Dermatol Clin. 2016;34:97-109.

80. Jemec GB, Guerin A, Kaminsky M, Okun M, Sundaram M. What happens after a single surgical intervention for hidradenitis suppurativa? A retrospective claims-based analysis. J Med Econ. 2016;19:710-7.

81. Blok JL, Boersma M, Terra JB, Spoo JR, Leeman FW, van den Heuvel ER, et al. Surgery under general anaesthesia in severe hidradenitis suppurativa: a study of 363 primary operations in 113 patients. J Eur Acad Dermatol Venereol. 2015;29: $1590-7$.

82. Janse IC, Hellinga J, Blok JL, van den Heuvel ER, Spoo JR, Jonkman MF, et al. Skintissue-sparing excision with electrosurgical peeling: a case series in hidradenitis suppurativa. Acta Derm Venereol. 2016;96:390-1.

83. Humphries LS, Kueberuwa E, Beederman M, Gottlieb LJ. Wide excision and healing by secondary intent for the surgical treatment of hidradenitis suppurativa: a single-center experience. J Plast Reconstr Aesthet Surg. 2016;69:554-66.

84. Maeda T, Kimura C, Murao N, Takahashi K. Promising long-term outcomes of the reused skin-graft technique for chronic gluteal hidradenitis suppurativa. J Plast Reconstr Aesthet Surg. 2015;68:1268-75.

85. Wormald JC, Balzano A, Clibbon JJ, Figus A. Surgical treatment of severe hidradenitis suppurativa of the axilla: thoracodorsal artery perforator (TDAP) flap versus split skin graft. J Plast Reconstr Aesthet Surg. 2014;67:1118-24.

86. Yamashita Y, Hashimoto I, Matsuo S, Abe Y, Ishida S, Nakanishi H. Two-stage surgery for hidradenitis suppurativa: staged artificial dermis and skin grafting. Dermatol Surg. 2014;40:110-5.

87. Hurley H. Axillary hyperhidrosis, apocrine bromhidrosis, hidradenitis suppurativa, and familial benign pemphigus: surgical approach. Dermatol Surg. 1989: 729-39.

88. Revuz JE, Jemec GB. Diagnosing hidradenitis suppurativa. Dermatol Clin. 2016; $34: 1-5$.

89. Yu CC, Cook MG. Hidradenitis suppurativa: a disease of follicular epithelium, rather than apocrine glands. Br J Dermatol. 1990;122:763-9.

90. Boer J, Weltevreden EF. Hidradenitis suppurativa or acne inversa. A clinicopathological study of early lesions. Br J Dermatol. 1996;135:721-5.

91. Jemec GB, Hansen U. Histology of hidradenitis suppurativa. J Am Acad Dermatol. 1996;34:994-9.

92. Prens E, Deckers I. Pathophysiology of hidradenitis suppurativa: an update. J Am Acad Dermatol. 2015;73:S8-11.

93. von Laffert M, Helmbold P, Wohlrab J, Fiedler E, Stadie V, Marsch WC. Hidradenitis suppurativa (acne inversa): early inflammatory events at terminal follicles and at interfollicular epidermis. Exp Dermatol. 2010;19:533-7.
94. von Laffert M, Stadie V, Wohlrab J, Marsch WC. Hidradenitis suppurativa/acne inversa: bilocated epithelial hyperplasia with very different sequelae. $\mathrm{Br} J$ Dermatol. 2011;164:367-71.

95. van der Zee HH, de Ruiter L, van den Broecke DG, Dik WA, Laman JD, Prens EP. Elevated levels of tumour necrosis factor (TNF)-alpha, interleukin (IL)-1beta and IL-10 in hidradenitis suppurativa skin: a rationale for targeting TNF-alpha and IL-1beta. Br J Dermatol. 2011;164:1292-8.

96. Mozeika E, Pilmane M, Nurnberg BM, Jemec GB. Tumour necrosis factor-alpha and matrix metalloproteinase- 2 are expressed strongly in hidradenitis suppurativa. Acta Derm Venereol. 2013;93:301-4.

97. Emelianov VU, Bechara FG, Glaser R, Langan EA, Taungjaruwinai WM, Schroder $J M$, et al. Immunohistological pointers to a possible role for excessive cathelicidin (LL-37) expression by apocrine sweat glands in the pathogenesis of hidradenitis suppurativa/acne inversa. Br J Dermatol. 2012;166:1023-34.

98. Wolk K, Warszawska K, Hoeflich C, Witte E, Schneider-Burrus S, Witte K, et al. Deficiency of IL-22 contributes to a chronic inflammatory disease: pathogenetic mechanisms in acne inversa. J Immunol. 2011;186:1228-39.

99. Hunger RE, Surovy AM, Hassan AS, Braathen LR, Yawalkar N. Toll-like receptor 2 is highly expressed in lesions of acne inversa and colocalizes with C-type lectin receptor. Br J Dermatol. 2008;158:691-7.

100. Bechara FG, Sand M, Skrygan M, Kreuter A, Altmeyer P, Gambichler T. Acne inversa: evaluating antimicrobial peptides and proteins. Ann Dermatol. 2012;24:393-7.

101. Dreno B, Khammari A, Brocard A, Moyse D, Blouin E, Guillet G, et al. Hidradenitis suppurativa: the role of deficient cutaneous innate immunity. Arch Dermatol. 2012;148:182-6.

102. Schlapbach C, Hanni T, Yawalkar N, Hunger RE. Expression of the IL-23/Th17 pathway in lesions of hidradenitis suppurativa. J Am Acad Dermatol. 2011;65:790-8.

103. Thomi R, Yerly D, Yawalkar N, Simon D, Schlapbach C, Hunger RE. Interleukin-32 is highly expressed in lesions of hidradenitis suppurativa. Br J Dermatol. 2017; 177:1358-66.

104. Thomi R, Kakeda M, Yawalkar N, Schlapbach C, Hunger RE. Increased expression of the interleukin-36 cytokines in lesions of hidradenitis suppurativa. J Eur Acad Dermatol Venereol. 2017;31:2091-6.

105. Kelly G, Hughes R, McGarry T, van den Born M, Adamzik K, Fitzgerald R, et al. Dysregulated cytokine expression in lesional and nonlesional skin in hidradenitis suppurativa. Br J Dermatol. 2015;173:1431-9.

106. Hotz C, Boniotto M, Guguin A, Surenaud M, Jean-Louis F, Tisserand P, et al. Intrinsic defect in keratinocyte function leads to inflammation in hidradenitis suppurativa. J Invest Dermatol. 2016;136:1768-80.

107. Palmer RA, Keefe M. Early-onset hidradenitis suppurativa. Clin Exp Dermatol. 2001;26:501-3.

108. e-Boks A/S. e-boks.dk: Hvad er e-Boks? [Internet]. e-Boks A/S. [cited $2018 \mathrm{Mar}$ 23]. Available from: https://www.e-boks.com/danmark/da/hvad-er-e-boks/.

109. Desai N, Shah P. High burden of hospital resource utilization in patients with hidradenitis suppurativa in England: a retrospective cohort study using hospital episode statistics. Br J Dermatol. 2017;176:1048-55.

110. Sundhed.dk: Tilskud til medicin [Internet]. Sundhed.dk. [cited 2017 Dec 8]. Available from: https://www.sundhed.dk/borger/sygdom-og-medicin/medicin/ tilskud-til-medicin/.

111. Pro.medicin.dk: Tetracyclin [Internet]. Pro.medicin.dk. [cited 2017 Dec 8]. Available from: https://pro.medicin.dk/Medicin/Praeparater/8345.

112. Pro.medicin.dk: Clindamycin [Internet]. Pro.medicin.dk. [cited 2017 Dec 8]. Available from: https://pro.medicin.dk/Medicin/Praeparater/3959.

113. Pro.medicin.dk: Rifampicin [Internet]. Pro.medicin.dk. [cited 2017 Dec 8]. Available from: https://pro.medicin.dk/Medicin/Praeparater/561.

114. Ring HC, Sorensen H, Miller IM, List EK, Saunte DM, Jemec GB. Pain in hidradenitis suppurativa: a pilot study. Acta Derm Venereol. 2016;96:554-6. 